\title{
Supplementation of a maternal low-protein diet in rat pregnancy with folic acid ameliorates programming effects upon feeding behaviour in the absence of disturbances to the methionine-homocysteine cycle
}

\author{
Sarah F. Engeham, Andrea Haase and Simon C. Langley-Evans* \\ School of Biosciences, University of Nottingham, Sutton Bonington, Loughborough LE12 5RD, UK
}

(Received 18 June 2009 - Revised 4 September 2009 - Accepted 5 October 2009 - First published online 27 November 2009)

Maternal protein restriction in rat pregnancy is associated with altered feeding behaviour in later life. When allowed to self-select their diet, rats subject to prenatal undernutrition show an increased preference for fatty foods. The main aim of the present study was to evaluate the contribution of folic acid in the maternal diet to programming of appetite, since disturbances of the folate and methionine-homocysteine cycles have been suggested to impact upon epigenetic regulation of gene expression and hence programme long-term physiology and metabolism. Pregnant rats were fed diets containing either 9 or $18 \%$ casein by weight, with folate provided at either 1 or $5 \mathrm{mg} / \mathrm{kg}$ diet. Adult male animals exposed to low protein (LP) in fetal life exhibited increased preference for high-fat food. Providing the higher level of folate in the maternal diet prevented this effect of LP, but offspring of rats fed $18 \%$ casein diet with additional folate behaved in a similar manner to LP-exposed animals. Among day 20 gestation fetuses, it was apparent that both protein restriction and maternal folate supplementation could have adverse effects upon placental growth. Examination of methionine-homocysteine and folate cycle intermediates, tissue glutathione concentrations and expression of mRNA for methionine synthase, DNA methyltransferase 1 and methyltetrahydrofolate reductase revealed no gross disturbances of folate and one-carbon metabolism in either maternal or fetal tissue. The present findings indicated that any role for DNA methylation in programming of physiology is not related to major perturbations of folate metabolism, and is likely to be gene-specific rather than genome-wide.

Folate: Programming: Appetite: Rats: Pregnancy

Early life exposure to an adverse nutritional environment can programme aspects of adult anatomy, physiology and metabolism, and thereby determine risk of cardiovascular and metabolic disorders ${ }^{(1,2)}$. Retrospective cohort studies have demonstrated that markers of suboptimal maternal nutritional status during fetal development predict increased risk of obesity and the metabolic syndrome obesity in adult life ${ }^{(3,4)}$. Animal studies strongly support these epidemiological findings ${ }^{(5)}$. Experiments that have manipulated either overall food supply or dietary composition such that one or more nutrients are limiting indicate that the fetus mounts adaptive responses in order to preserve growth. The immediate outcomes of these adaptive responses are favourable, ensuring the immediate survival of the animal in a less than optimal fetal environment. In the longer term however, modifications to organ structure, hormone responsiveness or gene expression appear to predispose to metabolic disorders in later life ${ }^{(1)}$.

Animal models of nutritional programming suggest that obesity may be programmed by exposure to both under- and overnutrition during fetal life ${ }^{(6-8)}$. Some of this risk is associated with programming of feeding behaviour. For example, the offspring of rats fed a cafeteria diet during pregnancy show increased preferences for energy-dense 'junk' foods later in life ${ }^{(9)}$. Animals whose mothers underwent severe restriction of food intake in pregnancy exhibit hyperphagia coupled with reduced physical activity ${ }^{(10)}$. We have previously shown that exposure to a LP diet in fetal life modifies feeding behaviour in rats ${ }^{(11,12)}$. Low-protein feeding throughout gestation promoted a preference for high-fat foods in the young adult offspring. The magnitude of these effects was found to vary between the sexes, with more pronounced differences in feeding behaviour among females ${ }^{(11)}$. Timing of exposure to maternal undernutrition also had specific effects, with exposure to LP diet throughout fetal life having different effects to exposure in discrete periods of gestation ${ }^{(12)}$. Early life programming of feeding behaviour is likely to involve modification of central mechanisms that regulate intake, for example the serotonergic system ${ }^{(13)}$. Orozco-Sólis et al. ${ }^{(14)}$ reported that expression of orexigenic peptides was increased, and anorexigenic peptides decreased in the brains of animals exposed to LP diets in utero. There is evidence that protein restriction in early life may modify the volume and neuronal density in hypothalamic centres that regulate food intake ${ }^{(15)}$.

The fundamental mechanisms that mediate such changes in physiological and metabolic function are poorly understood. There is considerable interest in the contribution of epigenetic factors ${ }^{(16)}$. Protein restriction in rat pregnancy has been shown to promote hypomethylation of DNA at specific gene

Abbreviations: CON, control diet; CPF, control with folate diet; LP, low-protein diet; LPF, LP with folate diet.

* Corresponding author: Professor Simon C. Langley-Evans, fax +440115 9516139, email simon.langley-evans@nottingham.ac.uk 
promoters in liver, and may also modify histone acetylation and methylation ${ }^{(17-19)}$. Similarly, undernutrition of sheep in early pregnancy also led to widespread hypomethylation of $\mathrm{DNA}^{(20)}$. Ensuing changes in gene expression can be readily incorporated into explanations of how tissue anatomy and function become permanently altered. It has been argued that casein-based LP diets, supplemented with methionine to avoid $\mathrm{S}$ deficiency, could impact upon epigenetic regulation of gene expression by modifying the availability of methyl donors $^{(21)}$. This view is supported by reports that proteinrestricted pregnant rats have elevated plasma homocysteine concentrations in early gestation and that supplementation of LP diets with either glycine or folate can prevent the programming effects of undernutrition on both physiological outcomes such as blood pressure and upon DNA methylation patterns ${ }^{(22-26)}$. Such evidence appears to support the assertion that protein restriction perturbs metabolism of methionine, homocysteine and folate, but other studies have shown no differences in maternal or fetal homocysteine concentrations in late gestation ${ }^{(27)}$.

The primary aim of the present study was to establish whether previously observed effects of maternal protein restriction upon feeding behaviour could be prevented by supplementation of the maternal diet with folate. To further assess whether disturbances of maternal or fetal methionine-homocysteine and folate cycle metabolism might contribute to programming effects of LP diets, we also examined concentrations of a range of intermediates and the mRNA expression of important regulatory enzymes of these pathways.

\section{Materials and methods}

\section{Animals}

Two separate animal experiments were carried out under license from the UK Home Office, in accordance with the Animals (Scientific Procedures) Act 1986. In both trials, virgin female Wistar rats (Harlan, Belton, UK) were mated at between 180 and $225 \mathrm{~g}$ weight to stud males. Upon confirmation of pregnancy by the presence of a semen plug, the female rats were randomly allocated to be fed one of four synthetic diets (control diet $(\mathrm{CON})$ : $18 \%$ casein, $1 \mathrm{mg} / \mathrm{kg}$ folate; control with folate diet (CPF): $18 \%$ casein, $5 \mathrm{mg} / \mathrm{kg}$ folate; low-protein diet (LP): $9 \%$ casein, $1 \mathrm{mg} / \mathrm{kg}$ folate; $\mathrm{LP}$ with folate diet (LPF): $9 \%$ casein, $5 \mathrm{mg} / \mathrm{kg}$ folate). These were of the same composition to those used in earlier studies in our laboratory, comprising casein-based diets, with carbohydrate provided as a $2: 1 \mathrm{mix}(\mathrm{w} / \mathrm{w})$ of starch and sucrose. The full composition of the CON and LP diets is published elsewhere ${ }^{(28)}$. While CON and LP diets were prepared with a vitamin mix to deliver $1 \mathrm{mg}$ folic acid $/ \mathrm{kg}$ diet, CPF and LPF diets were formulated to provide $5 \mathrm{mg}$ folic acid $/ \mathrm{kg}$ diet. Weight and food intake were recorded daily for all animals during pregnancy. The folate concentrations in the supplemented diets were selected to duplicate earlier work by Torrens et al. ${ }^{(29)}$. The folate content of the CON was at the level recommended for laboratory rodents by the US National Research Council ${ }^{(30)}$.

In the first experiment, twenty-four pregnant rats were fed the semi-synthetic diets until they delivered pups at $22 \mathrm{~d}$ gestation. Upon delivery of pups, the mothers were transferred to a standard laboratory chow diet (B\&K Universal Ltd, Hull, $\mathrm{UK}$, rat and mouse diet) and the litters were culled to a maximum of eight pups (four males and four females where possible). This minimised variation in nutrition during the suckling period. The offspring from the four groups therefore differed only in terms of their prenatal dietary experience. At 3 weeks after birth, the pups were weaned and half of the animals were then culled using $\mathrm{CO}_{2}$ asphyxia and cervical dislocation, and tissue was collected, snap-frozen in liquid nitrogen and stored at $-80^{\circ} \mathrm{C}$. The remaining animals were maintained on standard laboratory chow and weighed weekly. At 12 weeks of age, one male and one female from each litter were placed on a self-selection macronutrient diet, which provided them with a choice of a high-protein food, a high-carbohydrate food and a high-protein food. The composition of these food items has been previously published $^{(11)}$. Our previous experience with this protocol is that although intake of the food sources is variable over the first $1-3 \mathrm{~d}$ after their introduction, recording intake over $5 \mathrm{~d}$ provides a reliable estimate of daily intake. In the present study, intake was measured daily between 09.00 and 11.00 hours, over a period of $7 \mathrm{~d}$. All rats were singly housed during this period. Body weights and intakes of each of the food types were measured daily. The animals were then culled at 13 weeks of age using $\mathrm{CO}_{2}$ asphyxia and cervical dislocation. Tissue was collected, snap-frozen in liquid nitrogen and stored at $-80^{\circ} \mathrm{C}$.

In the second experiment, pregnancies (twelve per group) were terminated at day 20 gestation for collection of tissues. Body weight gain and food intake were recorded daily. The pregnant rats were killed using $\mathrm{CO}_{2}$ asphyxia and cervical dislocation. Maternal blood was collected by cardiac puncture and transferred to heparin tubes. The maternal liver was rapidly dissected and snap-frozen in liquid nitrogen. The uterus was dissected, and fetuses were removed, separated from their placentas and, following weighing, were killed by destruction of the brain and decapitation for collection of blood samples. Each fetus had its sex determined by genitoanal distance, and the liver, heart and kidneys were dissected from each fetus, were weighed to the nearest $0.1 \mathrm{mg}$ and then snap-frozen in liquid nitrogen. Blood samples were centrifuged at $13000 \mathrm{rpm}$ at $4^{\circ} \mathrm{C}$ for $10 \mathrm{~min}$ and the plasma was retained. Organs and plasma were stored at $-80^{\circ} \mathrm{C}$ until used for further analyses.

\section{Dual X-ray absorptiometry}

Whole frozen carcasses were measured for bone mineral density, bone mineral content, fat and $\mathrm{H}_{2} \mathrm{O}$ contents using dual X-ray absorptiometry on a Lunar dual X-ray absorptiometry scanner. Estimates of carcass composition were made using software for small animal scanning.

\section{Determination of circulating metabolites}

Plasma glucose was measured using an absorptiometric assay based upon the method of Trinder ${ }^{(31)}$. Ten microlitres of glucose standard $(0-2 \mathrm{mg} / \mathrm{ml})$ or sample were loaded in duplicate onto a microplate, followed by $200 \mu$ glucose reagent $(50 \mathrm{mg}$ glucose oxidase, $8 \mathrm{mg}$ horseradish peroxidase, $1 \mathrm{~g} / \mathrm{l}$ 
Table 1. Primer and probe sequences

\begin{tabular}{lll}
\hline Cyclophilin A & Forward primer & CGATGACGAGCCCTTGG \\
& Reverse primer & TCTGCTGTCTTTGGAACTTGTC \\
DNA methyltransferase 1 & Probe & CGCGTCTCCTTCGAGCTGTTTGCA \\
& Forward primer & GGAAGGTGAGCATCGACGAA \\
& Reverse primer & GGTCATTCCGGATGATCCC \\
Methyltetrahydrofolate reductase & Probe & ACGCAGTCGCCACCTCCAGAG \\
& Forward primer & GAAGTGAGAGTTGGAAGGACAGTTC \\
& Reverse primer & GTCTCATCTTCTCCCGCAGTCT \\
Methionine synthase & Probe & CCTGGACCCGGACCGGAACG \\
& Forward primer & GTATCGCCCAGGCTGACTATG \\
& Reverse primer & CAAATGCTCCGCAGACGTG \\
& Probe & CATCCGGTAGGCCAAGTGTTCGAGG
\end{tabular}

2,2'-azino-di-[3-ethylbenzthiazoline sulphonate] in $0 \cdot 1 \mathrm{M}$ sodium phosphate, $\mathrm{pH} 7 \cdot 4$ ). The plate was incubated at $37^{\circ} \mathrm{C}$ for $15 \mathrm{~min}$ and then read on a plate reader (Tecan Sunrise, Männedorf, Switzerland) at $620 \mathrm{~nm}$. Homocysteine concentrations were measured in day 20 fetal and maternal plasma samples using a commercial kit (Diazyme, Poway, CA, USA). Total circulating plasma cholesterol and TAG were assayed using commercially available kits (ThermoTrace, Noble Park, Vic., Australia). Leptin was measured in plasma using a quantitative mouse leptin ELISA kit (Crystal Chem, Inc., Downers Grove, IL, USA). Insulin was determined in plasma using a quantitative rat insulin ELISA kit (Crystal Chem, Inc.). All kit-based assays were performed according to the manufacturer's instructions.

\section{Determination of folate}

For assays of tissue folate, $100 \mathrm{mg}$ liver was homogenised in $1 \mathrm{ml}$ sodium phosphate buffer. A $20 \mu \mathrm{l}$ aliquot was diluted 1:50 with sodium borate buffer for use in the folate assay. Folate was then measured in the liver preparation, or in plasma, using a RIA kit (folate/vitamin B $_{12}$ SimulTRAC $^{\circledR}$ DCC; MP Biomedicals, Illkirch, France), following the manufacturer's instructions. Maternal plasma was used undiluted, but fetal plasma was diluted 1:100.

\section{Determination of glutathione}

Hepatic glutathione concentrations were determined using an enzymatic method as described previously ${ }^{(32)}$. Two hundred milligrams of fresh liver were homogenised in $3 \mathrm{ml} 0.2 \mathrm{M}$ perchloric acid. Homogenates were centrifuged at $2000 \mathrm{rpm}$ for $10 \mathrm{~min}$, and the supernatant was used for assay.

\section{Determination of choline and phosphocholine}

Choline and phosphocholine were extracted from liver using a chloroform-methanol extraction. Two hundred milligrams of sample were homogenised in $1 \mathrm{ml}$ ice-cold $0 \cdot 145 \mathrm{M} \mathrm{NaCl}$. Ten millilitres of 2:1 chloroform-methanol were added, and samples were mixed for $30 \mathrm{~min}$ on a rotary mixer at room temperature. Three millilitres of distilled $\mathrm{H}_{2} \mathrm{O}$ were added,

Table 2. Body weight, composition and circulating metabolites in 4-week-old offspring*

(Mean values with their standard errors for $n$ observations per group)

\begin{tabular}{|c|c|c|c|c|c|c|c|c|c|c|c|c|c|c|c|c|}
\hline \multirow[b]{2}{*}{ Maternal diet } & \multirow[b]{2}{*}{ Sex } & \multirow[b]{2}{*}{$n$} & \multicolumn{2}{|c|}{ Wt (g) } & \multicolumn{2}{|c|}{$\begin{array}{l}\text { Gonadal fat } \\
\text { (\% body wt) }\end{array}$} & \multicolumn{2}{|c|}{$\begin{array}{l}\text { Perirenal fat } \\
\text { (\% body wt) }\end{array}$} & \multicolumn{2}{|c|}{$\begin{array}{l}\text { Glucose } \\
(\mathrm{mg} / \mathrm{l})\end{array}$} & \multicolumn{2}{|c|}{$\begin{array}{l}\text { Insulin } \\
\text { (ng/ml) }\end{array}$} & \multicolumn{2}{|c|}{$\begin{array}{l}\text { Cholesterol } \\
(\mathrm{mmol} / \mathrm{l})\end{array}$} & \multicolumn{2}{|c|}{ TAG (mmol/l) } \\
\hline & & & Mean & SEM & Mean & SEM & Mean & SEM & Mean & SEM & Mean & SEM & Mean & SEM & Mean & SEM \\
\hline \multirow[t]{2}{*}{ CON } & $M$ & 11 & 99 & 2 & 0.24 & 0.01 & 0.13 & 0.01 & 2.44 & 0.15 & 0.99 & 0.11 & $2 \cdot 22$ & 0.11 & 0.70 & 0.04 \\
\hline & $\mathrm{F}$ & 9 & 89† & 2 & $0.18 \dagger$ & 0.03 & 0.13 & 0.02 & $3 \cdot 19$ & 0.26 & 1.59 & 0.31 & $2 \cdot 53$ & 0.13 & 0.77 & 0.07 \\
\hline \multirow[t]{2}{*}{ CPF } & $M$ & 14 & 107 & 5 & $0.30 \ddagger$ & 0.02 & 0.16 & 0.02 & $2 \cdot 84$ & 0.33 & 0.87 & 0.11 & $2.58 \ddagger$ & 0.12 & 0.93 & 0.04 \\
\hline & $\mathrm{F}$ & 10 & $97 \dagger$ & 4 & $0.22 \dagger$ & 0.02 & 0.12 & 0.02 & $2 \cdot 61$ & 0.26 & 1.07 & 0.21 & $2 \cdot 66 \ddagger$ & 0.17 & 0.84 & 0.08 \\
\hline \multirow[t]{2}{*}{ LP } & $M$ & 8 & 97 & 5 & $0.30 \ddagger$ & 0.02 & 0.19 & 0.02 & 2.46 & 0.24 & $1.31 \S$ & 0.18 & $2 \cdot 28 \S$ & 0.09 & 0.97 & 0.10 \\
\hline & $\mathrm{F}$ & 12 & $88 \dagger$ & 3 & $0.19 \dagger$ & 0.02 & 0.12 & 0.01 & $2 \cdot 83$ & 0.23 & $1.39 \S$ & 0.18 & $2 \cdot 31 \S$ & 0.06 & 0.79 & 0.06 \\
\hline \multirow[t]{2}{*}{ LPF } & $M$ & 12 & 84 & 3 & $0.24 \S$ & 0.02 & 0.14 & 0.02 & 2.59 & 0.13 & 1.04 & 0.12 & $2.53 \ddagger$ & 0.09 & 0.93 & 0.12 \\
\hline & $\mathrm{F}$ & 11 & 78†‡§॥ & 3 & $0.20 \dagger$ & 0.02 & 0.13 & 0.02 & $2 \cdot 67$ & 0.20 & 1.07 & 0.16 & $2 \cdot 63 \ddagger \|$ & 0.07 & 0.81 & 0.05 \\
\hline \multicolumn{17}{|l|}{$P$-values } \\
\hline Effect of protein & & & \multicolumn{2}{|c|}{$<0.001$} & \multicolumn{2}{|c|}{ NS } & \multicolumn{2}{|c|}{ NS } & \multicolumn{2}{|c|}{ NS } & \multicolumn{2}{|c|}{ NS } & \multicolumn{2}{|c|}{ NS } & \multicolumn{2}{|c|}{ NS } \\
\hline Effect of folate & & & \multicolumn{2}{|c|}{ NS } & \multicolumn{2}{|c|}{ NS } & \multicolumn{2}{|c|}{ NS } & \multicolumn{2}{|c|}{ NS } & \multicolumn{2}{|c|}{0.019} & \multicolumn{2}{|c|}{0.003} & \multicolumn{2}{|c|}{ NS } \\
\hline Effect of sex & & & \multicolumn{2}{|c|}{0.002} & \multicolumn{2}{|c|}{$<0.001$} & \multicolumn{2}{|c|}{ NS } & \multicolumn{2}{|c|}{ NS } & $\mathrm{N}$ & & $\mathrm{N}$ & & & \\
\hline Protein $\times$ folate & & & 0.00 & & 0.0 & & & & $\mathrm{~N}$ & & $\mathrm{~N}$ & & $\mathrm{~N}$ & & $\mathrm{~N}$ & \\
\hline Folate $\times$ sex & & & NS & & $\mathrm{N}$ & & & & 0.0 & & $\mathrm{~N}$ & & $\mathrm{~N}$ & & $\mathrm{~N}$ & \\
\hline
\end{tabular}

CON, control diet; M, male; F, female; CPF, control with folate diet; LP, low-protein diet; LPF, LP with folate diet.

* Data were analysed using a mixed model ANOVA.

† Mean values were significantly different between $\mathrm{M}$ and $\mathrm{F}$ of the same group $(P<0.05)$.

$\ddagger$ Mean values were significantly different to CON (same sex, $P<0.05$ ).

$\S$ Mean values were significantly different to CPF (same sex, $P<0.05$ )

$\|$ Mean values were significantly different to LP (same sex, $P<0.05$ ).

ๆ $P$ values are shown for univariate effects and any significant interactions between factors. 
Table 3. Body weight and composition in 13-week-old offspring*

(Mean values with their standard errors for $n$ observations per group)

\begin{tabular}{|c|c|c|c|c|c|c|c|c|c|c|c|c|c|c|}
\hline \multirow[b]{2}{*}{ Maternal diet } & \multirow[b]{2}{*}{ Sex } & \multirow[b]{2}{*}{$n$} & \multicolumn{2}{|c|}{ Wt (g) } & \multicolumn{2}{|c|}{$\begin{array}{l}\text { Gonadal fat } \\
\text { (\% body wt) }\end{array}$} & \multicolumn{2}{|c|}{$\begin{array}{l}\text { Perirenal fat } \\
\text { (\% body wt) }\end{array}$} & \multicolumn{2}{|c|}{$\begin{array}{l}\text { Total fat } \\
\text { (\% body wt) }\end{array}$} & \multicolumn{2}{|c|}{ BMC (g) } & \multicolumn{2}{|c|}{ BMD (g/m2) } \\
\hline & & & Mean & SEM & Mean & SEM & Mean & SEM & Mean & SEM & Mean & SEM & Mean & SEM \\
\hline \multirow[t]{2}{*}{ CON } & M & 9 & 398 & 15 & 0.88 & 0.07 & 0.68 & $0 \cdot 13$ & $9 \cdot 89$ & $1 \cdot 21$ & $9 \cdot 54$ & 0.35 & 0.32 & 0.01 \\
\hline & $\mathrm{F}$ & 10 & $231 \dagger$ & 6 & 0.89 & 0.12 & 0.69 & 0.08 & $5.74 \dagger$ & 0.65 & $6 \cdot 18 \dagger$ & 0.11 & $0.30 \dagger$ & 0.01 \\
\hline \multirow[t]{2}{*}{ CPF } & M & 12 & 431 & 10 & 0.94 & 0.06 & 0.91 & 0.10 & 11.74 & 1.68 & $10 \cdot 52$ & 0.20 & 0.34 & 0.01 \\
\hline & $\mathrm{F}$ & 11 & $243 \dagger$ & 5 & 0.93 & 0.11 & $0.56 \dagger$ & 0.07 & $5.47 \dagger$ & 0.60 & $6.38 \dagger$ & 0.16 & $0.30 \dagger$ & 0.01 \\
\hline \multirow[t]{2}{*}{ LP } & M & 10 & 421 & 15 & 1.00 & 0.07 & 0.90 & $0 \cdot 10$ & $10 \cdot 98$ & 1.36 & $10 \cdot 16$ & 0.33 & 0.33 & 0.01 \\
\hline & $\mathrm{F}$ & 10 & $245 \dagger$ & 11 & 0.98 & 0.12 & 0.69 & $0 \cdot 12$ & $8 \cdot 24 \dagger$ & 1.60 & 6.63† & 0.33 & $0.31 \dagger$ & 0.01 \\
\hline \multirow[t]{2}{*}{ LPF } & M & 10 & 420 & 13 & 0.94 & 0.06 & $1 \cdot 01$ & 0.08 & $14 \cdot 25 \ddagger$ & 1.56 & $11 \cdot 0 \ddagger$ & 0.45 & $0.35 \ddagger \S$ & 0.01 \\
\hline & $\mathrm{F}$ & 9 & $238 \dagger$ & 8 & 0.87 & 0.09 & $0.59 \dagger$ & $0 \cdot 10$ & $6 \cdot 84 \dagger$ & 0.93 & $6 \cdot 75 \dagger$ & 0.20 & $0.32 † \ddagger \|$ & 0.01 \\
\hline \multicolumn{15}{|l|}{$P$-values $\|$} \\
\hline Effect of protein & & & \multicolumn{2}{|c|}{ NS } & \multicolumn{2}{|c|}{ NS } & \multicolumn{2}{|c|}{ NS } & \multicolumn{2}{|c|}{0.039} & \multicolumn{2}{|c|}{ NS } & \multicolumn{2}{|c|}{0.009} \\
\hline Effect of folate & & & \multicolumn{2}{|c|}{0.031} & \multicolumn{2}{|c|}{$\begin{array}{l}\text { NS } \\
\text { NS }\end{array}$} & \multicolumn{2}{|c|}{ NS } & \multicolumn{2}{|c|}{ NS } & \multicolumn{2}{|c|}{$<0.001$} & \multicolumn{2}{|c|}{0.043} \\
\hline Effect of sex & & & $<0.0$ & & & & \multirow{2}{*}{\multicolumn{2}{|c|}{ NS }} & $<0.0$ & & $<0$ & & $<0.0$ & \\
\hline Sex $\times$ folate & & & \multicolumn{2}{|c|}{ NS } & \multicolumn{2}{|c|}{ NS } & & & \multicolumn{2}{|c|}{ NS } & \multicolumn{2}{|c|}{0.026} & \multicolumn{2}{|c|}{ NS } \\
\hline
\end{tabular}

BMC, bone mineral content; BMD, bone mineral density; CON, control diet; M, male; F, female; CPF, control with folate diet; LP, low-protein diet; LPF, LP with folate diet.

* Data were analysed using a mixed model ANOVA.

$\dagger$ Mean values were significantly different between $\mathrm{M}$ and $\mathrm{F}$ of the same group $(P<0.05)$.

$\ddagger$ Mean values were significantly different to CON (same sex, $P<0.05$ ).

$\S$ Mean values were significantly different to CPF (same sex, $P<0.05$ ).

\| Mean values were significantly different to LP (same sex, $P<0.05$ ).

I $P$ values are shown for univariate effects and any significant interactions between factors.

and samples were mixed by inverting three times. Following centrifugation at $3000 \mathrm{rpm}$ for $10 \mathrm{~min}$ at $20^{\circ} \mathrm{C}$, the aqueous phase was removed and placed to one side. Three millilitres of chloroform-methanol- $0 \cdot 145 \mathrm{M} \mathrm{NaCl}$ (3:48:47) were added, and the remaining organic phase, homogenate and tubes were subjected to a further $15 \mathrm{~min}$ spin on the rotary mixer. Samples were centrifuged at $3000 \mathrm{rpm}$ for $10 \mathrm{~min}$ at $20^{\circ} \mathrm{C}$. The aqueous phase was removed and added to the previous collection. The combined aqueous phase was then frozen at $-80^{\circ} \mathrm{C}$ and then freeze-dried. The resulting powder was dissolved in $1 \mathrm{ml} 50 \mathrm{~mm}$ 2-amino-2-(hydroxymethyl)propane-1,3-diol-HCl buffer. Between 25 and
$30 \mathrm{mg}$, charcoal was added, and the solution was vortexed and centrifuged for $2 \mathrm{~min}$ at $10000 \mathrm{rpm}$. Choline and phosphocholine were then measured using the absorptiometric assay of Blaton et al. ${ }^{(33)}$, adapted for use on a microplate reader (Tecan Sunrise).

\section{Quantitative real-time PCR}

mRNA expression was determined by quantitative real-time PCR using a Roche LightCycler 480, as reported previously $^{(34)}$. Total RNA was isolated from snap-frozen livers using the TRIzol method (Invitrogen, Paisley, UK).

Table 4. Circulating metabolites in 13-week-old offspring*

(Mean values with their standard errors for $n$ observations per group)

\begin{tabular}{|c|c|c|c|c|c|c|c|c|c|c|c|c|}
\hline \multirow[b]{2}{*}{ Maternal diet } & \multirow[b]{2}{*}{ Sex } & \multirow[b]{2}{*}{$n$} & \multicolumn{2}{|c|}{ Glucose (mg/l) } & \multicolumn{2}{|c|}{ Insulin (ng/ml) } & \multicolumn{2}{|c|}{$\begin{array}{l}\text { Leptin } \\
\text { (units } \mathrm{ng} / \mathrm{ml} \text { ) }\end{array}$} & \multicolumn{2}{|c|}{$\begin{array}{l}\text { Cholesterol } \\
(\mathrm{mmol} / \mathrm{l})\end{array}$} & \multicolumn{2}{|c|}{ TAG $(\mathrm{mmol} / \mathrm{l})$} \\
\hline & & & Mean & SEM & Mean & SEM & Mean & SEM & Mean & SEM & Mean & SEM \\
\hline \multirow[t]{2}{*}{ CON } & M & 9 & $2 \cdot 81$ & 0.32 & 2.53 & 0.55 & 0.30 & 0.03 & 1.85 & 0.15 & $1 \cdot 24$ & 0.22 \\
\hline & $\mathrm{F}$ & 10 & 3.14 & 0.32 & $1.16 \dagger$ & 0.15 & $0.24 \dagger$ & 0.03 & 1.65 & 0.20 & $0.52 \dagger$ & 0.05 \\
\hline \multirow[t]{2}{*}{ CPF } & M & 12 & 3.07 & 0.11 & $2 \cdot 16$ & 0.57 & 0.43 & 0.05 & $1 \cdot 70$ & 0.29 & 1.72 & 0.15 \\
\hline & $\mathrm{F}$ & 11 & $2 \cdot 69$ & 0.17 & 1.95 & 0.27 & $0.20 \dagger$ & 0.01 & 1.60 & 0.11 & $0.71 \dagger$ & $0 \cdot 11$ \\
\hline \multirow[t]{2}{*}{ LP } & M & 10 & 2.91 & 0.30 & $3 \cdot 18$ & 0.58 & 0.46 & 0.09 & 1.65 & $0 \cdot 17$ & 1.45 & 0.20 \\
\hline & $\mathrm{F}$ & 10 & $2 \cdot 50$ & 0.27 & $2 \cdot 64$ & 0.51 & $0.31 \dagger$ & 0.06 & 1.52 & 0.14 & $0.72 \dagger$ & 0.11 \\
\hline \multirow[t]{2}{*}{ LPF } & M & 10 & $2 \cdot 76$ & 0.29 & $2 \cdot 57$ & 0.45 & 0.41 & 0.03 & 1.82 & 0.16 & 1.69 & 0.23 \\
\hline & $\mathrm{F}$ & 9 & $2 \cdot 50$ & 0.30 & $1.47 \dagger$ & $0 \cdot 19$ & $0.20 \dagger$ & 0.02 & 1.77 & 0.09 & $0.59 \dagger$ & 0.08 \\
\hline \multicolumn{13}{|l|}{$P$-valuesł } \\
\hline \multirow{2}{*}{\multicolumn{3}{|c|}{$\begin{array}{l}\text { Effect of protein } \\
\text { Effect of folate }\end{array}$}} & \multicolumn{2}{|c|}{ NS } & \multicolumn{2}{|c|}{ NS } & \multicolumn{2}{|c|}{ NS } & \multicolumn{2}{|c|}{ NS } & \multicolumn{2}{|c|}{ NS } \\
\hline & & & \multicolumn{2}{|c|}{ NS } & \multicolumn{2}{|c|}{ NS } & \multicolumn{2}{|c|}{ NS } & \multicolumn{2}{|c|}{ NS } & \multicolumn{2}{|c|}{ NS } \\
\hline Effect of sex & & & \multicolumn{2}{|c|}{ NS } & \multirow{2}{*}{\multicolumn{2}{|c|}{$\begin{array}{l}0.006 \\
0.039\end{array}$}} & \multicolumn{2}{|c|}{$<0.001$} & \multicolumn{2}{|c|}{ NS } & \multirow{2}{*}{\multicolumn{2}{|c|}{$\begin{array}{c}<0.001 \\
\text { NS }\end{array}$}} \\
\hline Protein $\mathrm{x}$ folate & & & \multicolumn{2}{|c|}{ NS } & & & \multicolumn{2}{|c|}{ NS } & \multicolumn{2}{|c|}{ NS } & & \\
\hline
\end{tabular}

CON, control diet; M, male; F, female; CPF, control with folate diet; LP, low-protein diet; LPF, LP with folate diet.

${ }^{*}$ Data were analysed using a mixed model ANOVA.

† Mean values were significantly different between males and females of the same group $(P<0.05)$.

$\ddagger P$ values are shown for univariate effects and any significant interactions between factors. 

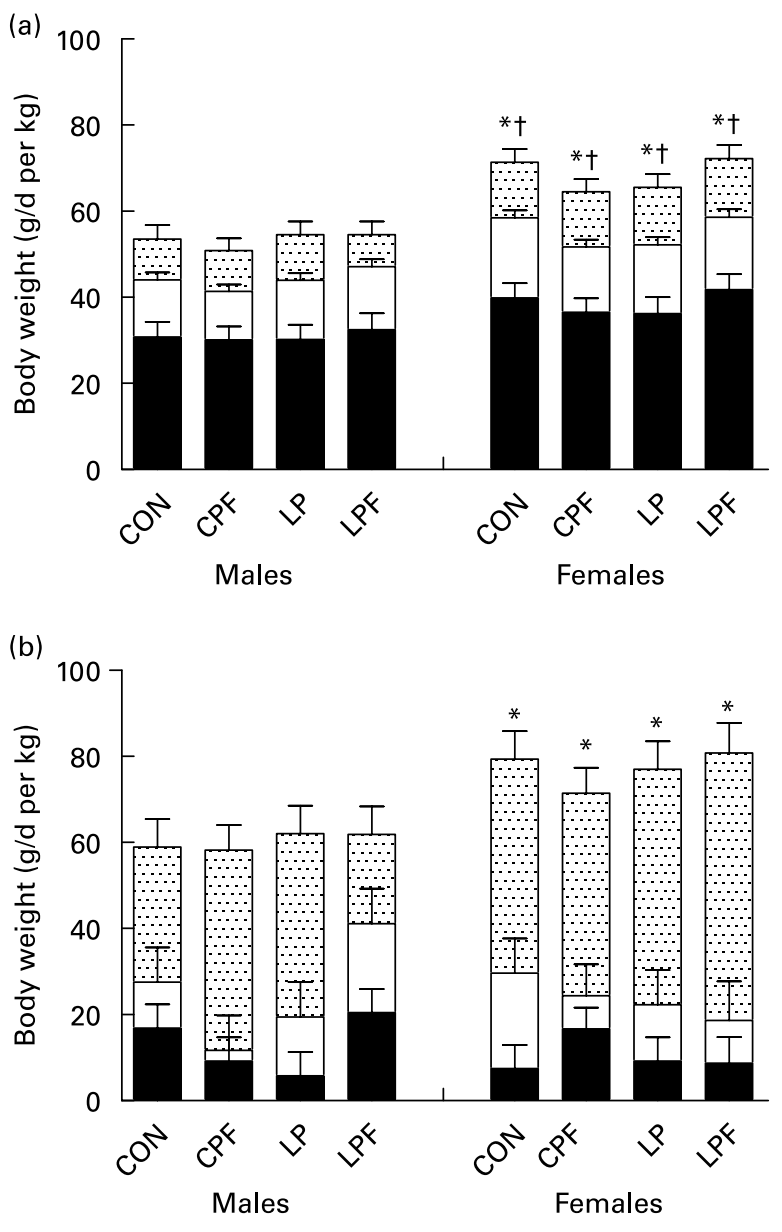

Fig. 1. Food and macronutrient intakes in rats provided with a self-selection diet. (a) Rats were given free access to separate protein-, carbohydrate $(\mathrm{CHO})$ - and fat-rich foods. Consumption of macronutrients was calculated from intakes of each foodstuff. Data are shown as means with their standard errors for $n$ as shown in Table 2. ANOVA indicated significant $(P<0.001)$ effects of sex upon intakes of protein and $\mathrm{CHO}$. * Mean values were significantly different for protein intake compared to males of the same maternal dietary group $(P<0.001)$. † Mean values were significantly different for protein intake compared to males of the same maternal dietary group $(P<0.001)$. (b) Rats were given free access to separate protein-, $\mathrm{CHO}$ - and fat-rich foods. Intakes of each foodstuff were monitored daily for $7 \mathrm{~d}$. Data are shown as means with their standard errors for $n$ as shown in Table 2. ANOVA indicated a significant effect of sex upon intakes of the fat-rich food $(P<0.001)$. Intakes of the $\mathrm{CHO}$-rich food $(P=0.047)$ and the fat-rich food $(P=0.015)$ were influenced by the three-way interaction of maternal protein intake $\times$ maternal folate intake $\times$ offspring sex. ${ }^{*}$ Mean values were significantly different for protein intake compared to males of the same maternal dietary group $(P<0.001)$. CON, control diet; CPF, control with folate diet; LP, low-protein diet; LPF, LP with folate diet. $\mathbf{\square}, \mathrm{CHO} ; \square$, protein; $\mathrm{B}$, fat.

The RNA was treated with DNase (Promega, Southampton, UK) and subjected to phenol-chloroform extraction and ethanol precipitation. Using Moloney murine leukemia virus RT (Promega), $0.5 \mu \mathrm{g}$ total RNA was reverse transcribed. Real-time RT-PCR was performed using the Roche LightCycler 480. A template-specific primer pair and an oligonucleotide probe (Sigma-Genosys, Haverhill, UK) specific to each of methyltetrahydrofolate reductase, methionine synthase and DNA methyltransferase 1 and the housekeeping gene cyclophilin A were designed using Primer Express version 1.5 (Applied Biosystems, Foster City, CA, USA).
The full sequences of the primers and probes are shown in Table 1. All primer sets were tested under the LightCycler PCR conditions using rat genomic DNA as a template. In all cases, a single product of the appropriate size was detected by gel electrophoresis (data not shown). A negative template control and relative standard curve were included on every PCR run. The standard curve was prepared from a pool of sample cDNA at relative dilutions of $0 \cdot 05,0 \cdot 1,0 \cdot 2,0 \cdot 4,1 \cdot 0$, 2.5 and 5.0. Relative target quantity was calculated from the standard curve, and all samples were normalised to cyclophilin A expression.

\section{Cytosine extension assay}

A cytosine extension assay was used to assess DNA methylation in CCGG sites throughout the genome ${ }^{(35,36)}$. One microgram of genomic DNA, isolated using Qiagen DNeasy kits, was digested with the restriction enzymes Msp I and $H p a$ II. DNA was also mock digested with $\mathrm{H}_{2} \mathrm{O}$ as an internal control. Each digestion was performed in triplicate in a mixture of $0.4 \mu \mathrm{l}$ bovine serum albumin (Promega), $6 \mu \mathrm{l}$ of the appropriate restriction enzyme buffer (Promega), $3 \mu l$ of appropriate restriction enzyme (Promega) or $\mathrm{H}_{2} \mathrm{O}$ and $0.6 \mu \mathrm{l}$ double-distilled $\mathrm{H}_{2} \mathrm{O}$ (Sigma, Borehamwood, Hertfordshire, $\mathrm{UK})$ to make a final volume of $30 \mu \mathrm{l}$ per reaction. The reaction was incubated overnight at $37^{\circ} \mathrm{C}$. Fifteen microlitres of each digested DNA sample were then transferred to a fresh Eppendorf tube, where $40 \mu$ l cytosine extension master mix containing $10 \mu \mathrm{l}$ DNA polymerase buffer (Promega), $4 \mu \mathrm{l}$ of $25 \mathrm{~mm}$ magnesium chloride (Promega), 0.25 $\mu \mathrm{l}$ DNA polymerase (Promega), 25.6744 $\mu$ l double-distilled $\mathrm{H}_{2} \mathrm{O}$ and $0.0756 \mu \mathrm{l}$ of $9.249 \mathrm{MBq} \quad(250 \mu \mathrm{Ci}) \quad\left[{ }^{3} \mathrm{H}\right] \mathrm{dCTP}, \quad$ specific activity $2 \times 10^{6} \mathrm{MBq}(59 \cdot 0 \mathrm{Ci}) / \mathrm{mmol}$ (Amersham, Buckinghamshire, UK) per reaction. The mixture was then incubated at $56^{\circ} \mathrm{C}$ for $1 \mathrm{~h}$ before being cooled on ice for $5 \mathrm{~min}$. Ten microlitres of each reaction were then transferred to DE-81 ion exchange filters (Whatman, Buckinghamshire, UK) and washed three times with $300 \mu \mathrm{l}$ of $0.5 \mathrm{M}$ sodium phosphate buffer, $\mathrm{pH} 7 \cdot 0$. The filters were then washed with $150 \mu$ l of $75 \%$ ethanol (Fisher, Leicestershire, UK) and allowed to air dry for $30 \mathrm{~min}$. The filters were then transferred to scintillation vials where $4 \mathrm{ml}$ scintillant (Perkin-Elmer, Cambridge, UK) was added. The incorporation of $\left[{ }^{3} \mathrm{H}\right] \mathrm{dCTP}$ was then counted using a TRI-CARB 2100TR liquid scintillation analyzer (Perkin-Elmer). The counts for the mock digestion were considered as the background count for that DNA sample and were subtracted from both the Msp I and Hpa II counts. In order to normalise the data for inconsistent amounts of starting material, for each sample, the ratio between the Hpa II and Msp I counts was determined as an index of DNA methylation.

\section{Statistical analysis}

All data were analysed using the Statistical Package for Social Sciences (SPSS, Inc., Chicago, IL, USA; version 14.0). Differences between groups were assessed using a mixed model ANOVA (fixed factors, maternal protein intake, maternal folate intake and offspring sex), unless indicated otherwise in the text. Values are expressed as means with their standard 
Table 5. Maternal weight gain and food intake*

(Mean values with their standard errors for $n 6$ observations)

\begin{tabular}{|c|c|c|c|c|c|c|c|c|c|}
\hline & \multirow[b]{3}{*}{ Days of gestation } & \multicolumn{8}{|c|}{ Dietary group } \\
\hline & & \multicolumn{2}{|c|}{ CON } & \multicolumn{2}{|c|}{ CPF } & \multicolumn{2}{|c|}{ LP } & \multicolumn{2}{|c|}{ LPF } \\
\hline & & Mean & SEM & Mean & SEM & Mean & SEM & Mean & SEM \\
\hline \multirow[t]{3}{*}{ Wt gain (g) } & $0-7$ & 22.5 & 3 & $17 \cdot 8$ & 4 & 24.5 & 5 & $22 \cdot 3$ & 4 \\
\hline & $8-14$ & $27 \cdot 7$ & 3 & 30.4 & 5 & $27 \cdot 3$ & 4 & $26 \cdot 6$ & 4 \\
\hline & $15-20$ & $47 \cdot 1$ & 5 & $48 \cdot 4$ & 5 & $47 \cdot 2$ & 3 & 44.4 & 6 \\
\hline \multirow[t]{3}{*}{ Food intake $(\mathrm{g} / \mathrm{d})$} & $0-7$ & $18 \cdot 6$ & $1 \cdot 2$ & $19 \cdot 0$ & $2 \cdot 4$ & $21 \cdot 8$ & $3 \cdot 7$ & $20 \cdot 7$ & 2.9 \\
\hline & $8-14$ & $19 \cdot 3$ & 1.6 & $18 \cdot 1$ & 1.8 & $20 \cdot 2$ & 4.0 & $18 \cdot 9$ & $2 \cdot 1$ \\
\hline & $15-22$ & $18 \cdot 7$ & 0.9 & $18 \cdot 7$ & $3 \cdot 7$ & $20 \cdot 1$ & $3 \cdot 2$ & $18 \cdot 9$ & 2.5 \\
\hline
\end{tabular}

CON, control diet; CPF, control with folate diet; LP, low-protein diet; LPF, LP with folate diet.

${ }^{*}$ No significant effects of maternal protein or folate intake were observed.

errors. $P<0.05$ was considered as significant. As multiple pups from the same dam were used throughout the present study, litter of origin was included as a fixed nested factor in all analyses ${ }^{(37)}$.

\section{Results}

In the first experiment, there was no evidence that the different dietary protocols impacted significantly on maternal weight gain across the full pregnancy (CON: 137 (SEM 3)g, CPF: 112 (SEM 4)g, LP: 136 (SEM 4)g, LPF: 128 (SEM 5)g), maternal food intake (CON: 23.1 (SEM 4.1) g/d, CPF: $22 \cdot 2$ (SEM 3.2) g/d, LP: 26.1 (SEM 3.6) g/d, LPF: 25.8 (SEM 2.4) g/d) or litter size (CON: 11 (SEM 4) pups, CPF: 10 (SEM 3) pups, LP: 12 (SEM 3) pups, LPF: 13 (SEM 5) pups). There were no postnatal deaths in any of the groups. At 4 weeks of age, body weight and abdominal fat deposition were largely unaffected by protein restriction or folate supplementation during the fetal period (Table 2). However, it was apparent that in female weanlings body weight was lower in the LPF group than all other groups, which was indicative of a protein $\times$ folate interaction $(P=0.001)$. Among animals exposed to the control level of protein in the maternal diet, folate supplementation was associated with greater deposition of gonadal fat. In contrast, offspring of mothers fed LP diets had smaller gonadal fat pads if exposed to folate supplementation. While plasma TAG concentrations were similar in all groups of animals (Table 2), glucose, insulin and cholesterol concentrations were influenced by maternal folate supplementation. Comparing CPF to CON and LPF to LP indicated that male offspring in the folate-supplemented groups tended to have higher, while females had lower glucose concentrations. Offspring from folate-supplemented groups had lower insulin and higher total cholesterol concentrations than the unsupplemented groups.

At 13 weeks of age, influences of maternal folate and protein intakes were more readily apparent (Table 3). Offspring of the CPF mothers tended to be heavier (NS) than those in the CON group, but no differences in fat pad weights were noted. Analysis of total carcass fat using dual $\mathrm{X}$-ray absorptiometry suggested that overall adiposity was significantly increased by maternal protein restriction and unaffected by folate supplementation. Bone mineralisation was also subject to programming influences. The rats exposed to maternal protein restriction had greater bone mineral density, but similar bone mineral content when compared to controls. Folate supplementation also tended to increase bone mineral density $(P=0.043)$ and produced significant increases in bone mineral content $(P<0.001)$, particularly in the LPF group. In contrast to the younger animals, circulating glucose, insulin, cholesterol and TAG concentrations (Table 4) were largely unaffected by protein restriction and folate supplementation. Folate supplementation of the maternal diet resulted in lower insulin concentrations in all but the female CPF group, where insulin was higher than in the corresponding $\mathrm{CON}$ group.

Table 6. Maternal circulating and tissue metabolites at day 20 gestation

(Mean values with their standard errors for $n 6-12$ observations)

\begin{tabular}{|c|c|c|c|c|c|c|c|c|}
\hline & \multicolumn{8}{|c|}{ Dietary group } \\
\hline & \multicolumn{2}{|c|}{ CON } & \multicolumn{2}{|c|}{$\mathrm{CPF}$} & \multicolumn{2}{|c|}{ LP } & \multicolumn{2}{|c|}{ LPF } \\
\hline & Mean & SEM & Mean & SEM & Mean & SEM & Mean & SEM \\
\hline Haematocrit (\%) & $41 \cdot 0$ & 1.6 & $38 \cdot 8$ & $4 \cdot 6$ & $36 \cdot 8$ & 1.8 & $37 \cdot 7$ & 1.0 \\
\hline TAG $(\mathrm{mmol} / \mathrm{l})$ & 3.54 & 0.59 & 3.45 & 0.48 & 3.81 & 0.75 & 3.36 & 0.57 \\
\hline Cholesterol (mmol/l) & 2.55 & 0.09 & $2 \cdot 74$ & 0.09 & $2 \cdot 38$ & $0 \cdot 10$ & 2.49 & 0.15 \\
\hline Glucose $(g / l)$ & 1.46 & 0.09 & 1.51 & 0.12 & 1.65 & 0.22 & 1.51 & 0.09 \\
\hline Liver GSH ( $\mu \mathrm{mol} / \mathrm{g}$ tissue) & 5.00 & 0.33 & 4.89 & 0.30 & $5 \cdot 19$ & 0.47 & $5 \cdot 17$ & 0.55 \\
\hline Liver choline (nmol/g tissue) & $775 \cdot 8$ & $101 \cdot 8$ & $885 \cdot 8$ & $75 \cdot 0$ & $872 \cdot 4$ & $86 \cdot 7$ & 843.5 & $99 \cdot 2$ \\
\hline Liver phosphocholine ( $\mu \mathrm{mol} / \mathrm{g}$ tissue) & 4.48 & 0.53 & 6.84 & 0.68 & 6.76 & $1 \cdot 21$ & 7.35 & 0.66 \\
\hline
\end{tabular}

CON, control diet; CPF, control with folate diet; LP, low-protein diet; LPF, LP with folate diet; GSH, total glutathione. 

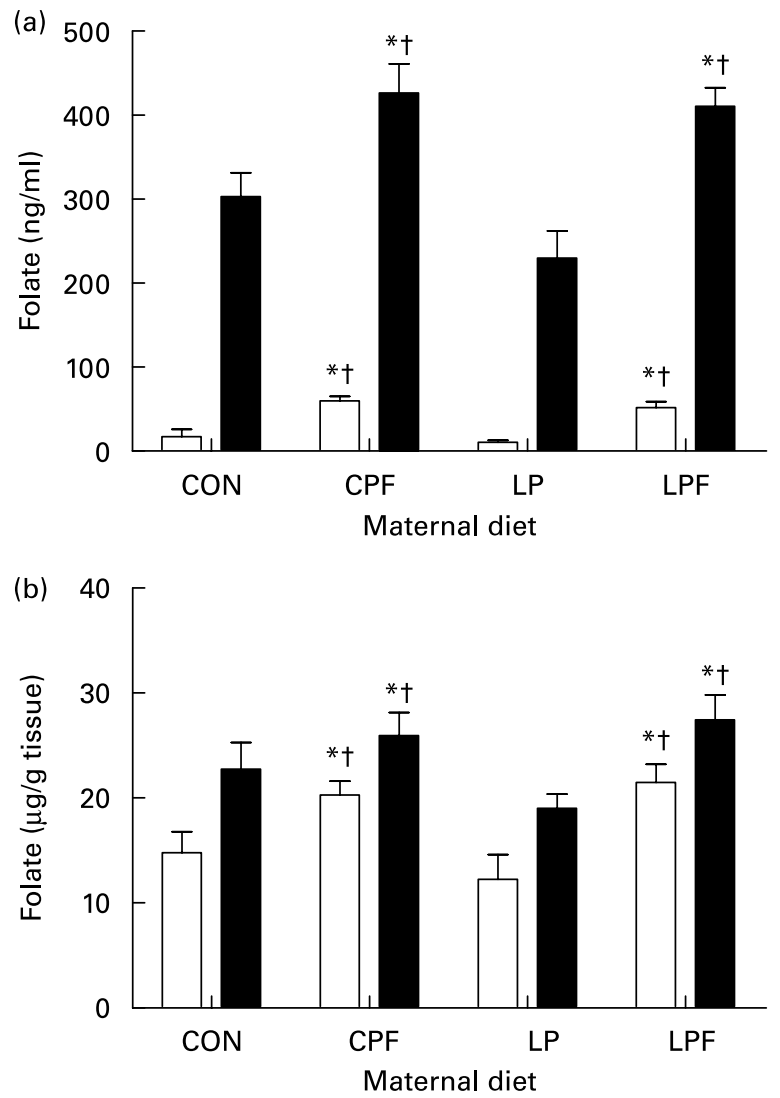

Fig. 2. Plasma and hepatic folate concentrations at day 20 gestation. (a) Folate concentrations in plasma from day 20 gestation mothers and fetuses. Data are shown as means with their standard errors for $n$ 10-12 observations. Folate concentration was significantly influenced by maternal folate intake $(P<0.001$ for both maternal and fetal measurements). * Mean values were significantly different to control diet $(\mathrm{CON} ; P<0.001)$. † Mean values were significantly different to low-protein diet (LP; $P<0.001$ ). (b) Folate concentrations in liver from day 20 gestation mothers and fetuses Data are shown as means with their standard errors for $n$ 9-12 (maternal) or $n$ 18-20 (fetal) observations. Folate concentration was significantly influenced by maternal folate intake $(P<0.001$ for both maternal and fetal measurements). * Mean values were significantly different to $C O N$ $(P<0.001)$. † Mean values were significantly different to LP $(P<0.001)$. CPF, control with folate diet; LPF, LP with folate diet. $\square$, Maternal; $\mathbf{\square}$, fetal.

Thirteen-week-old offspring were provided with a free choice of high-fat, high-protein and high-carbohydrate foods. On this diet regimen, it was apparent that females tended to consume more of all food types and hence had significantly greater intakes of protein and carbohydrate than males (per $\mathrm{kg}$ body weight). Considering macronutrient intake (Fig. 1(a)), there were no maternal diet-related differences in intakes of fat, carbohydrate or protein. As we have noted previously $^{(11)}$, intakes of specific foods were, however, influenced by interactions of sex with maternal protein and folate intakes (Fig. 1(b)). Of the three foods offered to the animals, the protein-rich item was the least consumed and no significant influences of maternal diet were noted. The high-fat item was most consumed by all animals and intakes were greater in females than in males. Among the males, fetal exposure to a LP diet resulted in a greater intake of high-fat food $(35 \%$ greater than $\mathrm{CON})$. The addition of folate to the maternal LP diet (LPF) resulted in a greatly reduced preference for high-fat food (34\% lower than CON). In contrast, the CPF males consumed the greatest amount of high-fat food among all groups. Among females, there were similar preferences for high-fat food noted among CON, CPF and LP groups. LPF females had significantly greater intakes of this food item than all other groups. Total food intake (all three food items together) was greater in females than in males. In both sexes, CON and LP groups had similar food intakes. Addition of folate to the LP diet had no major impact upon the subsequent food intakes of the offspring, but the same supplementation of the CON diet resulted in offspring tending to have lower food intake. This effect was stronger in females than in males (CPF males $4 \%$ lower than $\mathrm{CON}$ and $\mathrm{CPF}$ females $10 \%$ lower than $\mathrm{CON}$ ).

Table 5 shows the maternal weight gain and food intakes of the mothers used in the fetal trial. No significant effects of protein or folate concentration of the diet were noted. In the fetal trial, no significant diet-related differences were noted in maternal circulating and tissue metabolites, other than folate, at day 20 gestation (Table 6). Maternal plasma folate concentrations (Fig. 2(a)) and hepatic folate concentrations (Fig. 2(b)) were similar in the CON and LP groups. Addition of folate to either diet resulted in significant increases in folate status. Maternal plasma homocysteine concentrations (Fig. 3) were similar in all groups of animals. As shown in Table 7, the feeding of the LP diet resulted in significant differences in placental weights at day 20. Fetuses of the LP group were of similar weight to controls, but had smaller associated placentas, resulting in a larger fetal:placental ratio. Placentas associated with male, but not female, fetuses of the CPF group were smaller than those of control fetuses. In the LPF group, placentas were also smaller than in the CON group, but there was evidence that the addition of folate partially ameliorated the impact of LP feeding (Table 7).

Measurements of hepatic glutathione, choline and phosphocholine in day 20 fetuses indicated a minimal disturbance of metabolism associated with manipulation of maternal protein and folate intakes (Table 8). Hepatic phosphocholine concentrations were greater in LP and LPF male fetuses than in controls, and greater in LP than in CON females. Plasma and hepatic folate concentrations (Fig. 2) were greater in

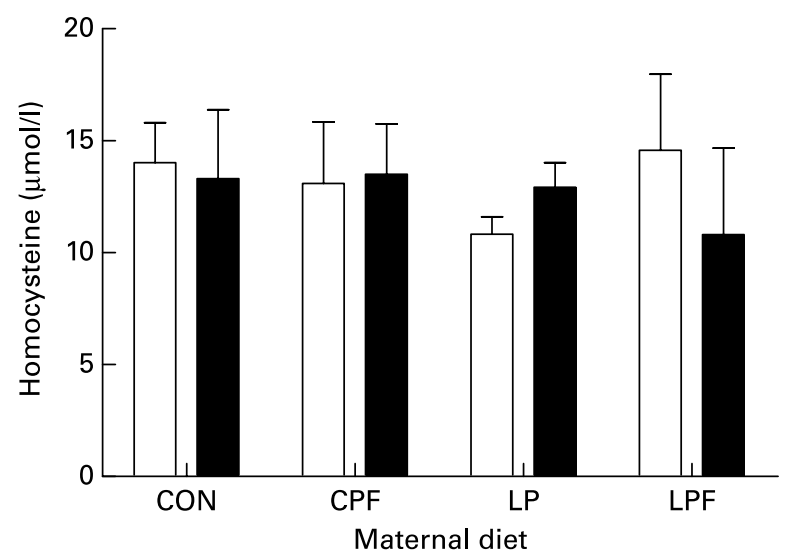

Fig. 3. Plasma homocysteine concentrations at day 20 gestation. Data are shown as means with their standard errors for $n 10-12$ observations. There were no significant effects noted. CON, control diet; CPF, control with folate diet; LP, low-protein diet; LPF, LP with folate diet. $\square$, Maternal; $\mathbf{\square}$, fetal. 
Table 7. Litter size, fetal and placental weights at day 20 gestation*

(Mean values with their standard errors for $n 12$ (litter size) and $n 95-126$ (fetal and placental weights) observations)

\begin{tabular}{|c|c|c|c|c|c|c|c|c|}
\hline & \multicolumn{8}{|c|}{ Dietary group } \\
\hline & \multicolumn{2}{|c|}{ CON } & \multicolumn{2}{|c|}{$\mathrm{CPF}$} & \multicolumn{2}{|c|}{ LP } & \multicolumn{2}{|c|}{ LPF } \\
\hline & Mean & SEM & Mean & SEM & Mean & SEM & Mean & SEM \\
\hline Litter size (no. of pups) & 13 & 1 & 13 & 1 & 13 & 1 & 13 & 1 \\
\hline \multicolumn{9}{|l|}{ Male fetuses } \\
\hline Fetal wt $(\mathrm{g})$ & $2 \cdot 82$ & 0.09 & $2 \cdot 82$ & 0.10 & $2 \cdot 90$ & 0.11 & $2 \cdot 85$ & 0.11 \\
\hline Placental wt (g) & 0.44 & 0.01 & $0.42 \dagger$ & 0.01 & $0.39 \dagger \ddagger$ & 0.01 & $0.41 \dagger$ & 0.01 \\
\hline Fetal:placental ratio & $6 \cdot 38$ & 0.18 & 6.53 & $0 \cdot 19$ & $7 \cdot 23+\ddagger$ & 0.23 & $6.92 \dagger \ddagger$ & 0.23 \\
\hline \multicolumn{9}{|l|}{ Female fetuses } \\
\hline Fetal wt (g) & $2.46 \S$ & 0.10 & $2.54 \S$ & $0.10 \S$ & $2.55 \S$ & $0 \cdot 11$ & $2.72 \S$ & 0.09 \\
\hline Placental wt (g) & 0.41 & 0.01 & 0.40 & 0.01 & $0.37 \dagger \ddagger$ & 0.01 & $0.38 \dagger$ & 0.01 \\
\hline Fetal:placental ratio & 5.93 & 0.22 & $6 \cdot 20$ & 0.22 & $6 \cdot 75 \dagger \ddagger$ & 0.26 & $7 \cdot 01 \dagger \ddagger$ & 0.22 \\
\hline
\end{tabular}

CON, control diet; CPF, control with folate diet; LP, low-protein diet; LPF, LP with folate diet.

${ }^{\star}$ Fetal and placental weights were influenced by sex $(P<0.001)$. Placental weight and the fetal:placental ratio were influenced by maternal protein intake $(P<0.001)$. Placental weight was influenced by the interaction of maternal protein and folate intakes $(P=0.016)$.

$\dagger$ Mean values were significantly different to CON (same sex, $P<0.05$ )

$\ddagger$ Mean values were significantly different to CPF (same sex, $P<0.05$ ).

$\S$ Mean values were significantly different between males and females of the same group $(P<0.05)$.

fetuses than in the mothers. CON and LP groups did not differ in folate status. CPF and LPF groups had significantly greater folate concentrations in both compartments. Fetal plasma homocysteine concentrations were similar in all four groups (Fig. 3). The expression of DNA methyltransferase 1, methyltetrahydrofolate reductase and methionine synthase mRNA was measured in fetal liver by quantitative real-time-PCR (Table 9). Although highly variable, there was no evidence that expression of any of these genes was influenced by maternal protein or folate status. Global methylation status was determined in liver, since this tissue has previously been shown to exhibit LP-programmed changes in gene expression and hypomethylation of specific gene promoters ${ }^{(19,23,25)}$. There was no evidence of differences in global DNA methylation as assessed by the cytosine extension assay in fetal liver (Fig. 4).

\section{Discussion}

Exposure to maternal protein restriction in fetal life is well established as a programming influence upon blood pressure regulation, renal development and the development of the metabolic syndrome ${ }^{(1)}$. In the present study, we chose to follow up reported programming effects upon food intake. Feeding behaviour of rats is subject to change in response to a variety of manipulations of the maternal diet. Vickers et al. ${ }^{(10)}$ reported that severe undernutrition $(70 \%$ restriction of maternal food intake) resulted in hyperphagic obesity in the resulting offspring. A similar outcome was noted in offspring of rats fed a LP diet in pregnancy and lactation ${ }^{(15)}$. Feeding of highly palatable human foods in pregnancy and lactation has been shown to increase the appetite of the offspring for the same profile of foods ${ }^{(9)}$. Variation in feeding behaviour following these insults in early life may be attributed to changes in the structure of hypothalamic centres such as the paraventricular or ventromedial nuclei, but may also stem from programming of the expression and release of regulatory neuropeptides and neurotransmitters. Pôrto et al. ${ }^{(13)}$ noted that $50 \%$ restriction of maternal food intake in the first 2 weeks of pregnancy led to defects of serotonergic regulation of appetite in the resulting offspring. Similar effects were reported by Lopes de Souza et al. ${ }^{(38)}$, following protein restriction in pregnancy and lactation. The same protocol was associated with decreased satiety, enhanced expression of agouti-related

Table 8. Fetal tissue metabolites at day 20 gestation

(Mean values with their standard errors for $n$ 11-17 observations)

\begin{tabular}{|c|c|c|c|c|c|c|c|c|}
\hline & \multicolumn{8}{|c|}{ Dietary group } \\
\hline & \multicolumn{2}{|c|}{ CON } & \multicolumn{2}{|c|}{ CPF } & \multicolumn{2}{|c|}{ LP } & \multicolumn{2}{|c|}{ LPF } \\
\hline & Mean & SEM & Mean & SEM & Mean & SEM & Mean & SEM \\
\hline \multicolumn{9}{|l|}{ Male fetuses } \\
\hline Liver GSH ( $\mu \mathrm{mol} / \mathrm{g}$ tissue) & 3.48 & 0.40 & 3.15 & 0.37 & 3.85 & 0.47 & 3.71 & 0.38 \\
\hline Liver choline (nmol/g tissue) & $1849 \cdot 3$ & $106 \cdot 9$ & $1827 \cdot 9$ & $107 \cdot 4$ & $2024 \cdot 5$ & $153 \cdot 3$ & $2024 \cdot 8$ & $144 \cdot 2$ \\
\hline Liver phosphocholine* ( $\mu \mathrm{mol} / \mathrm{g}$ tissue) & 15.52 & 0.98 & 16.04 & 1.02 & $17 \cdot 18$ & $1 \cdot 15$ & $18 \cdot 33$ & 0.61 \\
\hline \multicolumn{9}{|l|}{ Female fetuses } \\
\hline Liver GSH ( $\mu \mathrm{mol} / \mathrm{g}$ tissue) & 2.87 & 0.20 & $3 \cdot 30$ & 0.43 & 3.07 & 0.45 & $4 \cdot 11$ & 0.43 \\
\hline Liver choline (nmol/g tissue) & $1695 \cdot 0$ & $122 \cdot 3$ & 2055 & $147 \cdot 4$ & $1909 \cdot 8$ & $106 \cdot 9$ & $1864 \cdot 8$ & $164 \cdot 4$ \\
\hline Liver phosphocholine* ( $\mu \mathrm{mol} / \mathrm{g}$ tissue) & $15 \cdot 75$ & 0.82 & $17 \cdot 39$ & 0.95 & 18.05 & 0.85 & $16 \cdot 79$ & 0.57 \\
\hline
\end{tabular}

CON, control diet; CPF, control with folate diet; LP, low-protein diet; LPF, LP with folate diet; GSH, total glutathione.

${ }^{*}$ Phosphocholine concentrations were influenced by maternal protein intake $(P=0.028)$. 
Table 9. Fetal hepatic gene expression at day 20 gestation*

(Mean values with their standard errors for $n 5-10$ observations)

\begin{tabular}{|c|c|c|c|c|c|c|c|c|}
\hline & \multicolumn{8}{|c|}{ Dietary group } \\
\hline & \multicolumn{2}{|c|}{$\mathrm{CON}$} & \multicolumn{2}{|c|}{$\mathrm{CPF}$} & \multicolumn{2}{|c|}{ LP } & \multicolumn{2}{|c|}{ LPF } \\
\hline & Mean & SEM & Mean & SEM & Mean & SEM & Mean & SEM \\
\hline \multicolumn{9}{|l|}{ Male fetuses } \\
\hline DNA methyltransferase 1 & $5 \cdot 74$ & 2.07 & $4 \cdot 15$ & 0.51 & 3.38 & 0.48 & 6.66 & 3.67 \\
\hline Met synthase & 5.35 & 2.93 & $2 \cdot 84$ & 0.47 & 5.31 & 2.53 & 8.05 & $2 \cdot 67$ \\
\hline Methyltetrahydrofolate reductase & 14.02 & 4.77 & 9.45 & $2 \cdot 67$ & $12 \cdot 81$ & $4 \cdot 30$ & 8.05 & $2 \cdot 67$ \\
\hline \multicolumn{9}{|l|}{ Female fetuses } \\
\hline DNA methyltransferase 1 & $4 \cdot 12$ & 0.44 & $3 \cdot 64$ & 0.80 & $4 \cdot 20$ & 0.55 & $3 \cdot 18$ & 0.81 \\
\hline Met synthase & 2.45 & 0.48 & $2 \cdot 61$ & 0.44 & 3.59 & 0.79 & 3.95 & 0.87 \\
\hline Methyltetrahydrofolate reductase & $6 \cdot 69$ & 1.90 & $7 \cdot 88$ & 2.59 & $7 \cdot 11$ & 1.07 & 7.01 & 1.63 \\
\hline
\end{tabular}

CON, control diet; CPF, control with folate diet; LP, low-protein diet; LPF, LP with folate diet.

* All mRNA expression is shown as arbitrary units after normalisation of expression of cyclophilin A. Cyclophilin A was stably expressed across all groups in both sexes.

protein and neuropeptide $\mathrm{Y}$ and reduced expression of proopiomelanocortin. We have previously shown that in young adult rats exposed to LP throughout fetal life, the self-selection protocol applied in the present study uncovered a preference for high-fat food, although overall macronutrient intake was not vastly different ${ }^{(11,12)}$. This effect was absent in older rats and if the LP diet was targeted at single week periods of gestation, the preference was for carbohydraterich rather than fat-rich foods. Although in the present study the effect was limited to male offspring, we have largely replicated these earlier findings.

The novel aspect of the present work is that supplementation of the LP diet with folic acid prevented the programming of food preferences in male offspring. Folate supplementation was also noted to partly prevent the restriction of placental growth that was noted in LP pregnancies. It has been reported previously that the addition of either folate or glycine to a maternal LP diet could negate the programming impact of protein restriction upon blood pressure and cardiovascular function and upon renal development ${ }^{(22,29)}$. Such findings have contributed to the argument that onecarbon donors may play a critical role in the development and that limiting their availability may have adverse programming effects. In the context of behaviour, including feeding behaviour, choline is also a nutrient of interest since prenatal choline supply governs hippocampal neurogenesis ${ }^{(39)}$ and later performance in memory tests ${ }^{(40)}$ and conditioned behavioural responses $^{(41)}$. Folate deficiency in rat pregnancy is known to increase the availability of choline in maternal liver, whilst depleting phosphatidylcholine stores ${ }^{(36)}$. Interestingly, prenatal choline status determines the response of the older animal to choline in the adult diet. Analogous to this, Burdge et al. ${ }^{(23)}$ have recently reported that folic acid supplementation during the juvenile period in rats modifies the phenotype and epigenotype associated with prenatal protein restriction.

With evidence that increasing the availability of one-carbon donors can offset programming effects of a LP diet, it has been widely suggested that the protein restriction protocol interferes with metabolic pathways that contribute to availability of methyl donors for DNA methylation ${ }^{(21)}$. The ensuing disturbance of gene expression may then drive tissue remodelling and other processes that establish permanent programmed responses. Rees ${ }^{(21)}$ proposed that excessive methionine in the LP diet was a primary driver of this through perturbation of homocysteine metabolism, and hence $S$-adenosyl homocysteine and $S$-adenosyl methionine concentrations. In support of this argument, there have been reports of elevated homocysteine concentrations in early pregnancy, in response to LP feeding ${ }^{(24,26)}$. We assert that the present study, along with an earlier report ${ }^{(27)}$, largely lays this story to rest. Although DNA methylation undoubtedly plays a role in programming, there was no evidence that, in late gestation at least, the methionine-homocysteine cycle (assessed through measurement of homocysteine and expression of methionine synthase), folate cycle (assessed through measurement of total folate and expression of methyltetrahydrofolate reductase) or closely related processes (assessed through measures of tissue glutathione, phosphocholine and choline and expression of DNA methyltransferase 1) are significantly affected by protein restriction. Although limited by the sensitivity of the cytosine extension method, the present finding that global DNA methylation was not significantly altered

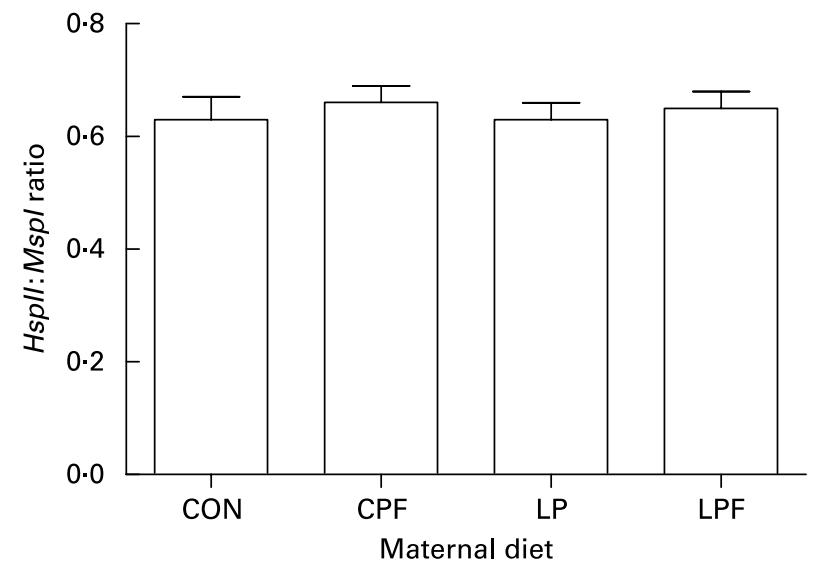

Fig. 4. Global DNA methylation measured through cytosine extension assay. Data are shown as means with their standard errors for $n$ 20-22 observations. No significant effects were noted. An increasing Hspll:Mspl ratio indicates an increasing proportion of cytosine-guanine sites being methylated. CON, control diet; CPF, control with folate diet; LP, low-protein diet; LPF, LP with folate diet. 
by either protein restriction or folate supplementation adds to the argument that epigenetic factors may contribute to nutritional programming at the level of specific gene promoters. For example, while Sinclair et al. ${ }^{(20)}$ noted a general hypomethylation response to restricted feeding in early sheep development, only $4 \%$ of 1400 loci exhibited this effect and at several of these sites, the effect was specific to male offspring. Burdge and colleagues ${ }^{(25)}$ noted that while the glucocorticoid receptor and PPAR $\alpha$ exhibited evidence of hypomethylation in liver following prenatal protein restriction, there was no evidence of altered methylation of the PPAR $\gamma$ promoter. The drivers of such differential methylation of DNA, or acetylation of histone proteins, are not fully understood.

There is a large body of evidence to suggest that long-term effects of maternal nutrition upon physiology and metabolism are related to modifications on the structures of major organs, including brain, kidney and pancreas ${ }^{(42-44)}$. Availability of methyl donors may be a driver of such tissue remodelling. Both choline and folate are known to impact upon the developing central nervous system ${ }^{(40)}$, and as mentioned above, availability of choline, in particular, during fetal development can be shown to influence behavioural traits in later life $\mathrm{f}^{(41,45)}$. Tissue growth and development is dependent upon cell division and this may be limited by the availability of nucleotides or replication of DNA. The synthesis of pyrimidine nucleotides is dependent upon the availability of $N 5, N 10$ methylene tetrahydrofolate. Similarly, the synthesis of purines requires both folate and glycine, both of which have been shown to prevent LP-related programming in the rat. Although we noted that there were no gross differences in total circulating and tissue folate in fetuses exposed to LP diet, it remains possible that the diet may subtly alter metabolic flux through the folate cycle. Preliminary evidence from our laboratory (Engeham et al., unpublished results) has indicated that there was less storage of polyglutamated forms of $\mathrm{N} 5, \mathrm{~N} 10$ methylene tetrahydrofolate and 5-methyltetrahydrofolate in maternal liver following supplementation of LP diet than in response to supplementation of the CON. This could be interpreted as being indicative of differences in folate metabolism, or placental transfer to the fetus in pregnancy associated with protein restriction. However, we would argue that the lack of gross changes in the metabolite concentrations and gene expression noted in the present paper makes it unlikely that minor shifts in maternal storage are likely to impact upon fetal development, fetal folate status and programming-related mechanisms.

Folic acid was added to the diet for the CPF and LPF groups at a concentration that was five times higher than used in the CON and LP diets. Undoubtedly, this represents a high-dose supplementation of this nutrient. Maternal folate intake in CON and LP groups was approximately 19-26 $\mu \mathrm{g} / \mathrm{d}$, while the supplemented groups consumed $93-129 \mu \mathrm{g} / \mathrm{d}$. The level of supplementation was selected to match that used by Torrens et al. ${ }^{(29)}$ to demonstrate that the strategy could prevent programming of vascular dysfunction by maternal protein restriction, and by Lillycrop et al. ${ }^{(25)}$ to demonstrate that differential methylation of DNA following protein restriction was absent following folate supplementation. Maternal folate intake, in the unsupplemented groups, was appropriate for pregnant rats ${ }^{(30)}$. The lack of differences in food intake between supplemented and unsupplemented groups, their similar litter sizes and their comparable weight gains show that the supplemented diets were palatable, that the folate intakes were not excessive and were not having obvious deleterious effects. In the present study, the supplementation of folic acid was apparently against a background of adequate, rather than deficient, folate status. The extra folate may therefore be expected to only have deleterious effects. However, findings in relation to vascular function and gene expression $^{(25,29)}$ suggest that with the $1 \mathrm{mg} / \mathrm{kg}$ concentration, folate is somehow limiting in the diet when coupled with a LP intake. While it was clear that the level of folate supplementation used in the present experiments could prevent the appearance of differences in feeding behaviour resulting from prenatal protein restriction, it was also apparent that folate exerted programming effects in its own right. Consumption of higher levels of folic acid in rat pregnancy had differential effects depending on the protein content of the maternal diet. While supplementation of the LP diet resulted in greater bone mineral density at 13 weeks and a reduced preference for high-fat food in males, the offspring of CPF-fed mothers tended to have more abdominal fat and were hypercholesterolaemic relative to control animals at 4 weeks of age. Female offspring of the CPF group tended to have elevated plasma insulin at 13 weeks, and their male littermates had an increased preference for the high-fat food. These data suggest that supplementation of folate in pregnancy when the maternal diet is adequate may have some detrimental impact upon fetal development. This may be an important finding in the context of public-health measures to improve folate status through fortification or supplementation strategies. It has hitherto been assumed that only the elderly population may be put at risk by these approaches.

In conclusion, the present study has demonstrated that programmed differences in feeding behaviour, which follow on from prenatal protein restriction, can be prevented by the supplementation of the diet with folic acid. However, in some respects, the offspring of folate-supplemented rats consuming a protein-replete diet exhibit similar attributes to offspring of unsupplemented protein-restricted animals. The mechanism through which folate exerts these effects remains unclear, but our investigation suggests that there are no folate-reversible, gross differences in the folate or methionine-homocysteine cycles, in fetal or maternal tissue, during late gestation. Further work in this area should evaluate the possibility that folate supplementation has differential effects upon both tissue remodelling processes and markers of epigenetic regulation of gene expression at specific loci.

\section{Acknowledgements}

The present work was funded by the European Union (EARNEST, FOOD-CT-2005-007036) and a studentship from the Biotechnology and Biological Sciences Research Council. S. F. E. and A. H. conducted the animal trials. S. F. E. was responsible for all of the laboratory endpoints. S. C. L.-E. designed the experiment and performed the statistical analyses. All authors contributed to the writing of the paper. There are no conflicts of interest to declare. 


\section{References}

1. Langley-Evans SC (2006) Developmental programming of health and disease. Proc Nutr Soc 65, 97-105.

2. McMillen IC \& Robinson JS (2005) Developmental origins of the metabolic syndrome: prediction, plasticity, and programming. Physiol Rev 85, 571-633.

3. Salonen MK, Kajantie E, Osmond C, et al. (2009) Role of childhood growth on the risk of metabolic syndrome in obese men and women. Diabetes Metab 35, 94-100.

4. Ravelli GP, Stein ZA \& Susser MW (1976) Obesity in young men after famine exposure in utero and early infancy. $N$ Engl J Med 295, 349-353.

5. Langley-Evans SC (2009) Nutritional programming of disease: unravelling the mechanism. J Anat 215, 36-51.

6. Jones AP, Simson EL \& Friedman MI (1983) Gestational undernutrition and the development of obesity in rats. J Nutr 114, $1482-1484$.

7. Anguita RM, Sigulem DM \& Sawaya AL (1993) Intrauterine food restriction is associated with obesity in young rats. $J$ Nutr 123, 1421-1428.

8. Samuelsson AM, Matthews PA, Argenton M, et al. (2008) Dietinduced obesity in female mice leads to offspring hyperphagia, adiposity, hypertension, and insulin resistance: a novel murine model of developmental programming. Hypertension 51, 383-392.

9. Bayol SA, Farrington SJ \& Stickland NC (2007) A maternal 'junk food' diet in pregnancy and lactation promotes an exacerbated taste for 'junk food' and a greater propensity for obesity in rat offspring. Br J Nutr 98, 843-851.

10. Vickers MH, Breier BH, McCarthy D, et al. (2003) Sedentary behavior during postnatal life is determined by the prenatal environment and exacerbated by postnatal hypercaloric nutrition. Am J Physiol Regul Integr Comp Physiol 285, R271-R273.

11. Bellinger L, Lilley C \& Langley-Evans SC (2004) Prenatal exposure to a maternal low-protein diet programmes a preference for high-fat foods in the young adult rat. Br J Nutr 92, 513-520.

12. Bellinger L \& Langley-Evans SC (2005) Fetal programming of appetite by exposure to a maternal low-protein diet in the rat. Clin Sci 109, 413-420.

13. Pôrto LC, Sardinha FL, Telles MM, et al. (2009) Impairment of the serotonergic control of feeding in adult female rats exposed to intra-uterine malnutrition. Br J Nutr 101, 1255-1261.

14. Orozco-Sólis R, Lopes de Souza S, Barbosa Matos RJ, et al. (2009) Perinatal undernutrition-induced obesity is independent of the developmental programming of feeding. Physiol Behav 96, 481-492.

15. Plagemann A, Harder T, Rake A, et al. (2000) Hypothalamic nuclei are malformed in weanling offspring of low protein malnourished rat dams. $J$ Nutr 130, 2582-2589.

16. Godfrey KM, Lillycrop KA, Burdge GC, et al. (2007) Epigenetic mechanisms and the mismatch concept of the developmental origins of health and disease. Pediatr Res 61, 5R-10R.

17. Lillycrop KA, Slater-Jefferies JL, Hanson MA, et al. (2007) Induction of altered epigenetic regulation of the hepatic glucocorticoid receptor in the offspring of rats fed a protein-restricted diet during pregnancy suggests that reduced DNA methyltransferase-1 expression is involved in impaired DNA methylation and changes in histone modifications. Br J Nutr 97, 1064-1073.

18. Lillycrop KA, Phillips ES, Torrens C, et al. (2008) Feeding pregnant rats a protein-restricted diet persistently alters the methylation of specific cytosines in the hepatic PPAR alpha promoter of the offspring. Br J Nutr 100, 278-282.

19. Burdge GC, Slater-Jefferies J, Torrens C, et al. (2007) Dietary protein restriction of pregnant rats in the F0 generation induces altered methylation of hepatic gene promoters in the adult male offspring in the F1 and F2 generations. Br J Nutr 97, $7435-7439$

20. Sinclair KD, Allegrucci C, Singh R, et al. (2007) DNA methylation, insulin resistance, and blood pressure in offspring determined by maternal periconceptional B vitamin and methionine status. Proc Natl Acad Sci U S A 104, 19351-19356.

21. Rees WD (2002) Manipulating the sulfur amino acid content of the early diet and its implications for long-term health. Proc Nutr Soc 61, 71-77.

22. Jackson AA, Dunn RL, Marchand MC, et al. (2002) Increased systolic blood pressure in rats induced by a maternal low-protein diet is reversed by dietary supplementation with glycine. Clin Sci 103, 633-639.

23. Burdge GC, Lillycrop KA, Phillips ES, et al. (2009) Folic acid supplementation during the juvenile-pubertal period in rats modifies the phenotype and epigenotype induced by prenatal nutrition. J Nutr 139, 1054-1060.

24. Brawley L, Torrens C, Anthony FW, et al. (2004) Glycine rectifies vascular dysfunction induced by dietary protein imbalance during pregnancy. $J$ Physiol 554, 497-504.

25. Lillycrop KA, Phillips ES, Jackson AA, et al. (2005) Dietary protein restriction of pregnant rats induces and folic acid supplementation prevents epigenetic modification of hepatic gene expression in the offspring. J Nutr 135, 1382-1386.

26. Petrie L, Duthie SJ, Rees WD, et al. (2002) Serum concentrations of homocysteine are elevated during early pregnancy in rodent models of fetal programming. Br J Nutr 88, 471-477.

27. Langley-Evans SC, Lilley C \& McMullen S (2006) Maternal protein restriction and fetal growth: lack of evidence of a role for homocysteine in fetal programming. Br J Nutr 96, 578-586.

28. Langley SC \& Jackson AA (1994) Increased systolic blood pressure in adult rats induced by fetal exposure to maternal low protein diets. Clin Sci 86, 217-222.

29. Torrens C, Brawley L, Anthony FW, et al. (2006) Folate supplementation during pregnancy improves offspring cardiovascular dysfunction induced by protein restriction. Hypertension 47, 982-987.

30. National Research Council (US) Subcommittee on laboratory animal nutrition (1995) Nutrient Requirements of Laboratory Animals, 4th ed. Washington, DC: National Academy Press.

31. Trinder P (1969) Determination of blood glucose using an oxidase-peroxidase system with a non-carcinogenic chromogen. J Clin Pathol 22, 158-161.

32. Langley-Evans SC, Phillips GJ \& Jackson AA (1997) Fetal exposure to low protein maternal diet alters the susceptibility of young adult rats to sulfur dioxide-induced lung injury. J Nutr 127, 202-209.

33. Blaton V, De Buyzere M, Spincemaille J, et al. (1983) Enzymic assay for phosphatidylcholine and sphingomyelin in serum. Clin Chem 29, 806-809.

34. Yates Z, Tarling EJ, Langley-Evans SC, et al. (2009) Maternal undernutrition programmes atherosclerosis in the ApoE*3-Leiden mouse. Br J Nutr 101, 1185-1194.

35. Pogribny I, Yi P \& James SJ (1999) A sensitive new method for rapid detection of abnormal methylation patterns in global DNA and within $\mathrm{CpG}$ islands. Biochem Biophys Res Commun 262, 624-628.

36. Maloney CA, Hay SM \& Rees WD (2009) The effects of feeding rats diets deficient in folic acid and related methyl donors on the blood pressure and glucose tolerance of the offspring. Br J Nutr 101, 1333-1340.

37. Festing MF (2006) Design and statistical methods in studies using animal models of development. ILAR J 47, 5-14.

38. Lopes de Souza S, Orozco-Solis R, Grit I, et al. (2008) Perinatal protein restriction reduces the inhibitory action of serotonin on food intake. Eur J Neurosci 27, 1400-1408. 
39. Glenn MJ, Gibson EM, Kirby ED, et al. (2007) Prenatal choline availability modulates hippocampal neurogenesis and neurogenic responses to enriching experiences in adult female rats. Eur J Neurosci 25, 2473-2482.

40. Zeisel SH (2009) Epigenetic mechanisms for nutrition determinants of later health outcomes. Am J Clin Nutr 89, 1488S-1493S.

41. Lamoureux JA, Meck WH \& Williams CL (2008) Prenatal choline availability alters the context sensitivity of Pavlovian conditioning in adult rats. Learn Mem 15, 866-875.

42. Bennis-Taleb N, Remacle C, Hoet JJ, et al. (1999) A low-protein isocaloric diet during gestation affects brain development and alters permanently cerebral cortex blood vessels in rat offspring. J Nutr 129, 1613-1619.

43. Snoeck A, Remacle C, Reusens B, et al. (1990) Effect of a low protein diet during pregnancy on the fetal rat endocrine pancreas. Biol Neonate 57, 107-118.

44. Langley-Evans SC, Welham SJM \& Jackson AA (1999) Fetal exposure to a maternal low protein diet impairs nephrogenesis and promotes hypertension in the rat. Life Sci 64, 965-974.

45. Gutierrez R \& Simon SA (2008) Perinatal choline supplementation: a smart lifelong solution to age-related dementia. Front Neurosci 2, 135-136. 